\title{
競泳用男性水着がけのび姿勢および体幹の筋活動に及ぼす影響*
}

\author{
長谷川 貴大 ${ }^{* 1}$, 中島 求 $^{* 2}$

\section{Effects of Men's Swimsuits on Swimming Position and Muscle Activity of Body Trunk in Gliding Motion} \\ Takahiro HASEGAWA and Motomu NAKASHIMA ${ }^{* 2}$ \\ *2 Tokyo Institute of Technology. Dept. of Mechanical and Control Engineering \\ 2-12-1 Ookayama, Meguro-ku, Tokyo, 152-8552 Japan
}

\begin{abstract}
The objective of this study was to clarify the effects of men's swimsuits on swimming position and muscle activity of body trunk in gliding motion. For this objective, a swimming experiment to measure electromyogram and gliding position in sagittal plane simultaneously was conducted for 3 types of men's swimsuit (A, B and C). Next, we compared experimental results one-on-one between the swimsuits by ANOVA. The results of the experiment and ANOVA showed that in wearing Swimsuit C, compared to Swimsuits A and B, hip became lower to shoulder $(p<0.05)$, the hip joint became more extended ( $p<0.05$ ), and the muscle activity of ES (Erector Spinae) and drag coefficient had tendency to decrease. In addition, we established a new index for the effect of body trunk support, which corresponds to the muscle activity of ES considering the change in the hip joint angle. We confirmed statistically that Swimsuit $\mathrm{C}$ had effects of extending hip joint and/or reducing the muscle activity of ES $(p<0.05)$. The reason for this was considered to be that the high tension of Swimsuit $\mathrm{C}$ helped the hip extensor muscles.
\end{abstract}

Key Words : Sports Biomechanics, Sport Engineering, Swimming, Swimsuit, Gliding Motion, Muscle Activity

\section{1. 緒言}

近年, スポーツ科学の分野は大きく発展し, 数多くのスポーツや運動を対象として研究がおこなわれている. 運動動作の解析とともに，スポーツ用具の研究・開発は様々な競技の記録向上に大きく貢献しており，水泳にお いても例外ではない. 例えば，2009 年にローマで開催された世界水泳選手権において，世界記録が 43 個も更新 された要因の 1 つとして,「高速水着」と呼ばれたラバー系水着の開発が挙げられているように, 競泳における水 着の重要性が近年高まっている.

従来の水着に関する研究として, Toussaint ${ }^{(1)}$ らは Fast-skin 水着を着用した際のクロール泳時の自己推進時抵抗 を計測し，清水 ${ }^{(2)}$ ら人体模型を用いて水着の流体抵抗を計測している. これらの研究に代表されるように，従 来の水着の研究・開発の多くは, 水泳中の抗力に着目し, 抗力低減を目標としておこなわれてきた. しかし近年 では，抗力低減効果は頭打ちになりつつあり，それ以外の方法により選手のパフォーマンス向上を目指す方向が 現場から求められつつある。その一つが体幹サポート効果である. 体幹サポート効果は, 効果がない水着を着用 した際と比較して，同じ努力でより良い姿勢を取ることができる，もしくはより少ない努力で同じ姿勢を取るこ とができる効果ということができる。しかし，国際水泳連盟の規定により，競泳用男性水着は腰周りから膝上ま でしか覆うことができない. よって，水着によって覆われていない体幹の代表的な筋である春柱起立筋や腹直筋 に直接的に効果を及ぼすことは困難と考えられる。そのため，体幹サポート効果の発生メカニズムおよび効果の 大きさを解明する必要がある.

* 原稿受付 2012 年 4 月 18 日

*1 東京工業大学大学院

*2 正員, 東京工業大学 機械制御システム専攻（テ152-8552 東京都目黒区大岡山 2-12-1）

E-mail : motomu@mech.titech.ac.jp 
ここで，先に述べた体幹サポート効果の「姿勢」と「努力」について，努力度を表す指標は筋活動度であると

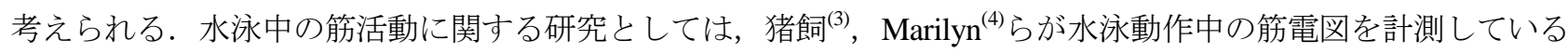
ものがある. しかし，水着が水中姿勢や筋活動に及ぼす影響に関する研究はみられず，その関係の有無も含めて わかっていない.

そこで本研究では，様々な競泳用男性水着を用いて，水泳における基本姿勢であるけのび姿勢時の水中姿勢お よび筋電図を実験的に測定し, 実験により取得したデータを用いて, 水着がけのび姿勢や水泳中の体幹の筋活動 に及ぼす影響を解明することを目的とする.

\section{2. 実験方法}

\section{$2 \cdot 1$ 被験者および試技内容}

本実験の被験者は，大学水泳部所属の男子競泳選手 5 名である. なお，いずれの選手も日本学生選手権水泳競 技大会において優秀な成績をおさめており，大学選手としては極めて優秀な部類に属する．被験者には，実験の 目的および方法について十分説明した後，書面にて実験への同意を得た．今回の実験では，被験者ごとにスター 卜位置（プール端）から $10 \mathrm{~m}$ までのタイムを設定し，各水着条件において，設定タイム \pm 0.5 秒となるように， 水中においてプール壁面を䟣ってけのびを 2 回ずつおこなわせた．これは，被験者ごとにタイムを揃えることに より，同一被験者内で同じ泳速度で泳ぐ際の筋発揮や水中姿勢を計測することができ，水着による筋活動やけの び姿勢の違いを比較しやすくするためである．各被験者の身体データおよび設定タイムを表 1 に示す．

Table 1 Data of subjects

\begin{tabular}{l|ccc}
\hline & Height $[\mathrm{cm}]$ & Weight $[\mathrm{kg}]$ & Set time $[\mathrm{s}]$ \\
\hline Subject i & 172.5 & 71.0 & 7.0 \\
\hline Subject ii & 181.0 & 80.0 & 6.2 \\
\hline Subject iii & 182.0 & 73.0 & 7.3 \\
\hline Subject iv & 175.0 & 71.0 & 7.8 \\
\hline Subject v & 188.0 & 87.0 & 6.1 \\
\hline
\end{tabular}

\section{$2 \cdot 2$ 競泳用男性水着の種類}

本研究では, 市販されている 3 種類の競泳用男性水着を用いて, 実験をおこなった. 各水着を着用した際の写 真を図 1 に示寸. Swimsuit A は, 腰から腿の付け根までを覆うショートスパッツ型水着であり, 競泳選手が普段 の練習時に着用寸ることが多いタイプである. Swimsuit B および Swimsuit C は, 腰から膝上までを覆うハーフス パッツ型水着である. 各水着の水着生地については, Swimsuit A および Swimsuit B にはニット素材が, Swimsuit C には布帛素材が用いられている，また，Swimsuit C は，体幹サポート効果が期待されるレース用水着であり，用 いられている布帛素材は Swimsuit AおよびSwimsuit B に使用されているニット素材と比較して張力が大きいとい う特徴がある。

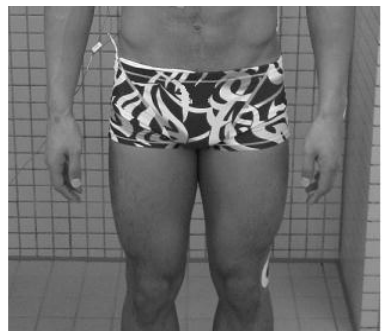

(a) Swimsuit A

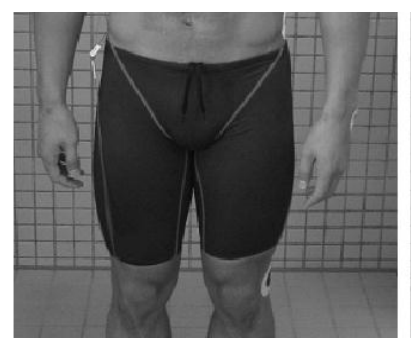

(b) Swimsuit B

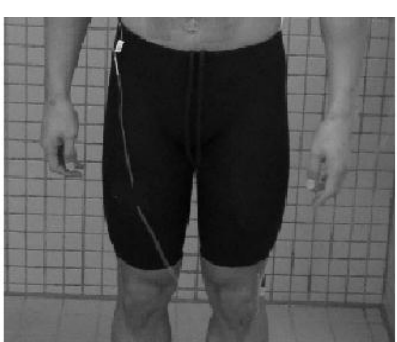

(c) Swimsuit C

Fig.1 Swimsuits 


\section{$2 \cdot 3$ 筋電図測定方法}

本実験では，春柱起立筋および腹直筋の筋電図を取得するために，表面筋電位測定器およびデータロガー（サ ンプリング周波数： $1 \mathrm{kHz}$ ）を用いて計測をおこなった. 水中において筋電位を正しく測定するために，防水テー プや液体絆創膏などを用いて防水した上で，体幹右側の各筋の該当箇所に表面皿電極を貼付した．筇電電極およ びアース電極の貼付位置を図 2 に示寸。また， Dankaerts ${ }^{(5)} ら の$ 研究を参考に，ダニエルスらの徒手筋力テストの 測定方法に従って，脊柱起立笳および腹直筋の MVC（Maximum Voluntary Contraction：最大随意収縮）時の筋電 図を別途陸上にて測定した.

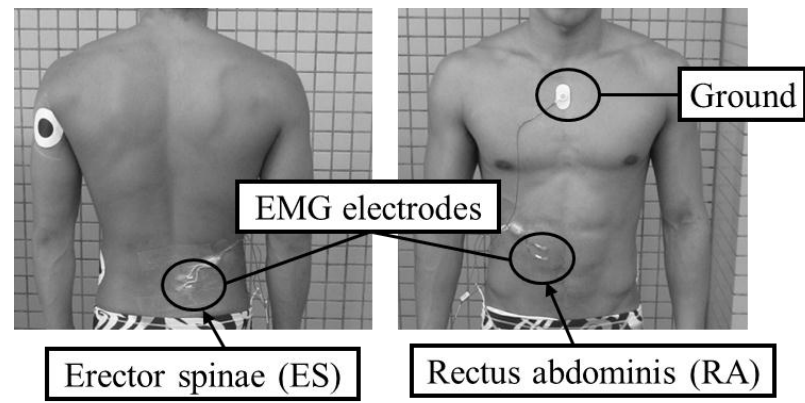

Fig.2 Attaching positions of EMG electrodes

\section{$2 \cdot 4$ 水中姿勢撮影方法}

矢状面内におけるけのび姿勢を測定するために，被験者の手首，肩，腰，膝，足首にマーカを貼付し，プール に固定された水中撮影用 CCD カメラ 1 台（フレームレート：30 fps）を用いて，水中姿勢映像を取得した．実際 に取得した水中撮影映像の一例を図 3 に示す.

また，筋電図測定用のデータロガーのスイッチを入れた際にLED ランプが発光する様子を，水中姿勢を撮影す るカメラと同期されたもう 1 台のカメラを用いて撮影することにより，撮影映像とデータロガーのデータの同期 を取った。

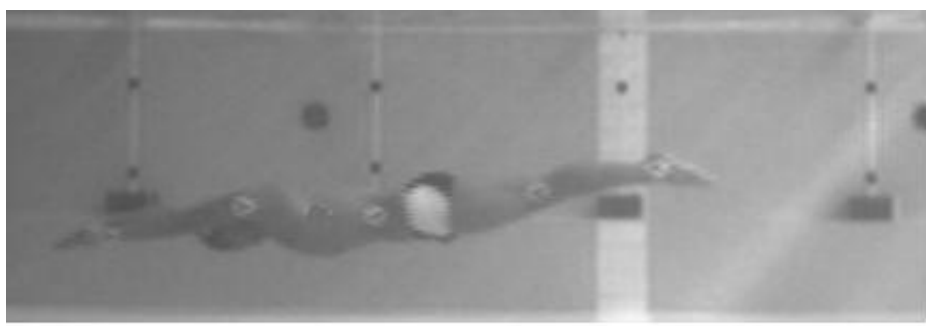

Fig.3 Image photographed by an underwater camera

\section{$2 \cdot 5$ 計測データの処理方法}

実験で取得したデータより，脊柱起立筋と腹直筋の筋活動，関節角，推進方向に対する体幹の絶対角，けのび 時の抗力係数を算出した．以下では，その処理方法を示寸．なお，計測データの処理については，試技中におい て安定したけのび姿勢を維持している時間範囲（概ねスタート後 $2.0 \mathrm{~s}$ から $5.0 \mathrm{~s}$ の間）のデータを用いた.

\section{$\mathbf{2} \cdot \mathbf{5} \cdot \mathbf{1}$ 関節角および推進方向に対する体幹の絶対角の算出方法}

けのび姿勢を評価するために，水泳実験で取得した水中撮影映像におけるマーカ座標より，肩関節，股関節， 膝関節の伸展 - 屈曲方向の関節角（以下，それぞれ肩関節角，股関節角，膝関節角）と，推進方向に対寸る体幹 の絶対角を算出した。以下にその算出方法を述べる. 
本研究では，手首マーカと肩マーカの線分を上肢，肩マーカと腰マーカの線分を体幹，腰マーカと膝マーカの 線分を腿，膝マーカと足首マーカの線分を脛として考え，矢状面内における水中姿勢を捉える，そこでまず，動 作解析ソフトウェアを用いて, 被験者に貼付した手首, 肩, 腰, 膝, 足首の 5 つのマ一の水中撮影映像内での 二次元座標を計測した. そして, 図 4(a)に示すように, 各マーカの二次元座標より, 上肢ベクトル $\boldsymbol{a}_{\text {arm }}$, 体幹べ クトル $\boldsymbol{a}_{\text {body }}$, 腿ベクトル $\boldsymbol{a}_{\text {thigh }}$, 脛ベクトル $\boldsymbol{a}_{\text {shank }}$ を算出した.

次に，肩関節角 $\theta_{\text {shoulder }}$ は上肢ベクトルと体幹ベクトルの相対角，股関節角 $\theta_{\text {hip }}$ は体幹ベクトルと腿ベクトルの 相対角，膝関節角 $\theta_{\text {knee }}$ は腿ベクトルと脛ベクトルの相対角としてそれぞれ定義し算出した．また，肩マーカの変 位から取得した水面方向に対する推進角度と，体幹ベクトルから取得した水面方向に対する体幹の絶対角度の值 より，推進方向に対する体幹の絶対角 $\theta_{b o d y}$ を算出した．肩関節角，股関節角，膝関節角および推進方向に対する 体幹の絶対角の模式図を図4(b)に示す.

また，本研究では，安定したけのび姿勢を維持している時間範囲の平均值を各試技の測定值とした.

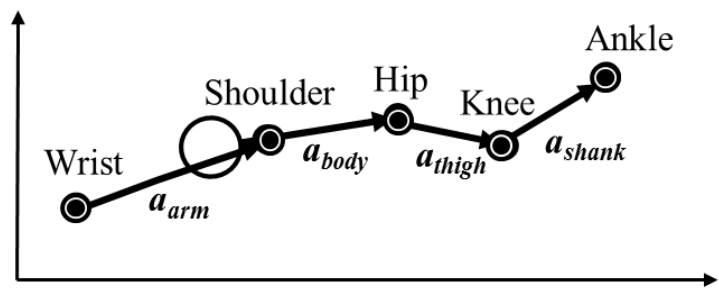

(a) Coordinate of markers and vectors of body segments

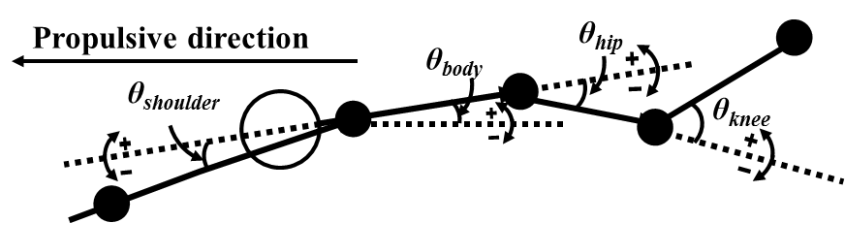

(b) Absolute angles of body to propulsive direction and joint angles

Fig.4 Definitions of body segments and joint angles in sagittal plane

\section{$2 \cdot 5 \cdot 2$ 筋電図の処理方法}

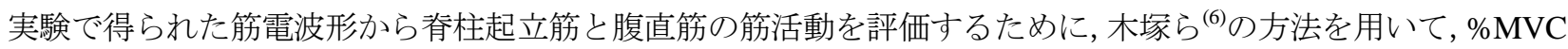
（最大筋発揮に対する割合）を算出した．まず，原波形を $20 \mathrm{~Hz}$ 以下および $500 \mathrm{~Hz}$ 以上の周波数成分を除去する バンドパスフィルタを用いてフィルタ処理した。次にフィルタ処理した波形を整流平滑化し，ARV（Average Rectified Value）を取得した.さらに得られた ARV を筋肉ごとに測定した MVC 時の ARVにより正規化し，\%MVC を算出した. 加えて，けのび時は水中姿勢が大きく変化しないことから，各筋の\%MVCも大きく変化しないと考 えられる，そこで，本研究では，安定したけのび姿勢を維持している時間範囲の\%MVC の平均值を平均\%MVC として算出し，平均\%MVC により各筋の筋活動を評価することとした.

\section{$2 \cdot 5 \cdot 3$ 抗力係数の算出方法}

本項では, 高木 ${ }^{(7)}$ らの研究を参考にした，けのび時の抗力係数の算出方法を説明する. まず，けのび時に働く流体抵抗 $F_{D}$ は以下の式で表すことができる.

$$
F_{D}=\frac{1}{2} \times C_{D} \rho S v(t)^{2}
$$

式(1)において， $C_{D}$ は抗力係数， $\rho$ は流体の密度， $S$ は体表面積， $v(t)$ は水面と平行な方向の速度である. なお，体 表面積は高比良 ${ }^{(8)}$ の推定式から算出した。 ここで, けのび時に働く力は流体抵抗のみと考え, 水面と平行な方向 の運動方程式より, 以下のように $v(t)$ を取得する. ただし, $m$ は被験者の質量, $A$ は積分定数, $\alpha=0.5 \times C_{D} \rho S$ であ る. 


$$
\begin{aligned}
m \times \dot{v}(t) & =-F_{D} \\
\Rightarrow & \int \frac{1}{v^{2}} \times d v=-\frac{\alpha}{m} \times \int d t \\
\Rightarrow v(t) & =\frac{1}{\frac{\alpha}{m} t+A}
\end{aligned}
$$

式(2)で求めた $v(t)$ を積分することにより, 水面と平行な方向の変位 $x(t)$ を求めると, 以下の式で表すことができ る.なお，B債分定数である.

$$
x(t)=\frac{m}{\alpha} \times \log \left(\frac{\alpha}{m} t+A\right)+B
$$

次に，水中撮影映像から取得した肩マーカ座標の時刻歴データを，最小二乗法によって式(3)に近似し， $\alpha / m$ を 取得した。そして，流体（水）の密度，被験者の質量，体表面積の值，および取得した $\alpha / m$ の值から，以下の式 (4)により，抗力係数を算出した.

$$
C_{D}=2 \times m \times \frac{\alpha}{m} \times \frac{1}{\rho S}
$$

肩マーカ座標の時刻歴データとその近似曲線をプロットしたグラフの一例を図 5 に示す. 図 5 より，時刻 歴データ (ドット) と近似曲線 (実線) がよく一致していることが確認できる.

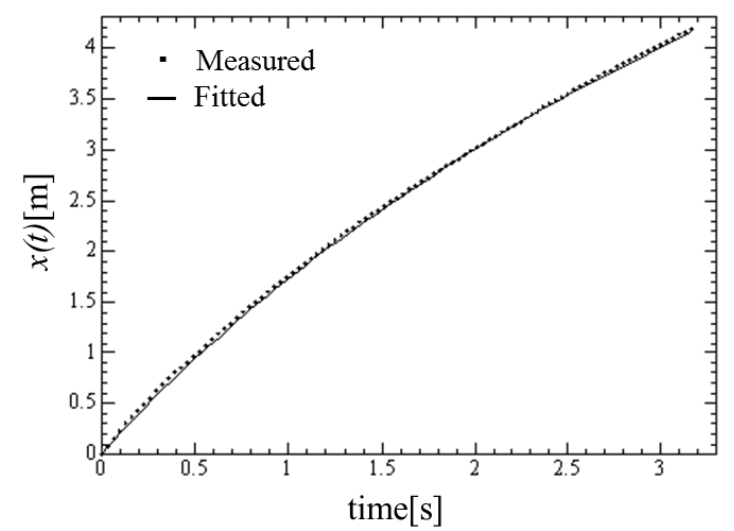

Fig.5 Example of time-displacement curve and fitted curve of shoulder marker

\section{3. 実験結果と考察}

\section{$3 \cdot 1$ 水着がけのび姿勢に及ぼす影響}

競泳用男性水着は，国際水泳連盟の規定により，最大で腰周りから膝上までしか覆うことができない。このこ とから，水着が直接的に水中姿勢に影響を及ぼすのは，股関節角と推進方向に対する体幹の絶対角であると推測 される，そこで本研究では，この2つの值に着目して，水着がけのび姿勢に及ぼす影響を考察する。 
まず，股関節角および推進方向に対する体幹の絶対角の実験結果を図 6 に示す．なお，図 6(a) において，正の 方向は股関節伸展方向, 負の方向は股関節屈曲方向であり, 図 6(b)については, 值が正ならば推進方向に対して 肩マーカよりも腰マーカが高い位置にあり，負ならば肩マーカよりも腰マーカが低いことを意味する.

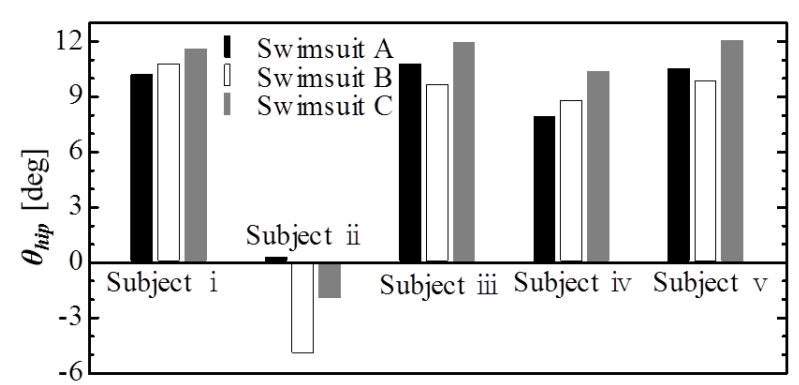

(a) Hip joint angle

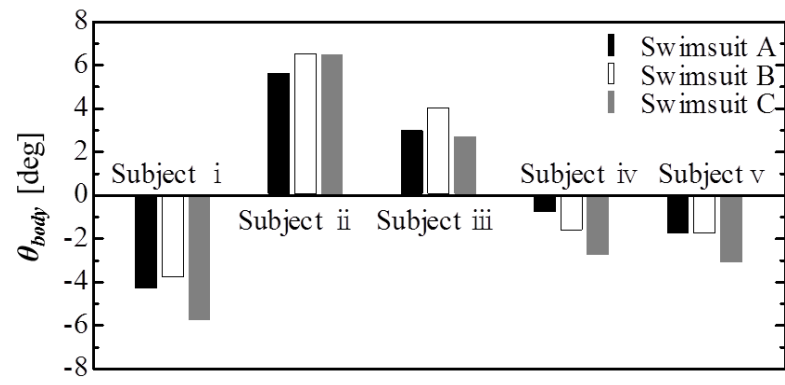

(b) Absolute angle of body to propulsive direction

Fig.6 Results of joint angles in sagittal plane

図 6(a)より，Swimsuit A や Swimsuit B を着用した際と比較して，Swimsuit C を着用した際に值が大きい，すな わち股関節角が伸展する傾向が確認できる. また, 図 6(b)の推進方向に対する体幹の絶対角については, Swimsuit C を着用した際に，他の水着を着用した際よりも，その值が負側に遷移寸る傾向が確認できる，なお，図 6(a)お よび(b)ともに，被験者間での值のばらつきが大きいが，この原因自体としては，被験者間でのけのび姿勢自体の ばらつきとともに, マーカ貼付位置のばらつきも考えられる. よって, 本研究では水着間の差についてのみ議論 し，值そのものについては議論しないこととする.

水着間の差についてより詳細に検討するため, 対馬(9)らの解析手順に従い，股関節角および推進方向に対する 体幹の絶対角について，Welch の補正による一元配置分散分析を用いて，水着間で一対一比較した．なお，被験 者間の值のばらつきを抑えてけのび姿勢を評価するために，一対一比較する片方の水着における実験結果を基準 として算出した角度差について，分散分析をおこなった．分散分析で取得した $p$ 值を表 2 および 3 に示す.

Table $2 p$-level in ANOVA for difference of hip joint angle

\begin{tabular}{c|cc}
\hline & $\begin{array}{c}\text { All subjects } \\
(\text { Subject i } \sim)\end{array}$ & $\begin{array}{c}\text { Except Subject ii } \\
(\text { Subject i, iii } \sim \text { v })\end{array}$ \\
\hline Swimsuit A vs. Swimsuit B & 0.365 & 0.868 \\
\hline Swimsuit A vs. Swimsuit C & 0.363 & 0.010 \\
\hline Swimsuit B vs. Swimsuit C & 0.005 & \\
\hline
\end{tabular}

Table $3 p$-level in ANOVA for difference of absolute angle of body to propulsive direction

\begin{tabular}{c|cc}
\hline & $\begin{array}{c}\text { All subjects } \\
\text { (Subject i } \sim \text { v) }\end{array}$ & $\begin{array}{c}\text { Except Subject ii } \\
\text { (Subject i, iii } \sim \text { v) }\end{array}$ \\
\hline Swimsuit A vs. Swimsuit B & 0.399 & 0.687 \\
\hline Swimsuit A vs. Swimsuit C & 0.174 & 0.037 \\
\hline Swimsuit B vs. Swimsuit C & 0.022 & \\
\hline
\end{tabular}


表 2 および表 3 より, 全被験者の実験結果においては, Swimsuit C を着用した際に Swimsuit B を着用した際と 比較して有意に股関節角が大きいこと $(p=0.005<0.01)$, 推進方向に対する体幹の絶対角が負側に遷移すること （ $p=0.022<0.05 ）$ が確認できる. また, Subjectii を除いた 4 名の被験者については, Swimsuit C を着用した際に, Swimsuit A を着用した際と比べて, 統計学的に有意に股関節角が正に大きくなること $(p=0.010<0.05)$, 推進方向 に対する体幹の絶対角が負側に遷移すること $(p=0.037<0.05)$ が同様に確認できる. Subject ii についても Swimsuit B と Swimsuit C の実験結果には有意な差があることから, 概ね全被験者に共通して, Swimsuit C は他の水着と比 較して，股関節をより伸展させる効果，および推進方向に対して肩の位置よりも腰の位置がより低くなる効果が 統計学的に確認できたと言える.このようなけのび姿勢は，図７に示すような，推進方向に対して臀部をより鉛 直下向きに引っ込めた姿勢（推進方向に対して体がより反った姿勢）であるといえる，なお，Swimsuit Aおよび Swimsuit B 着用時の，股関節角，推進方向に対する体幹の絶対角については，有意な差が確認されなかった．

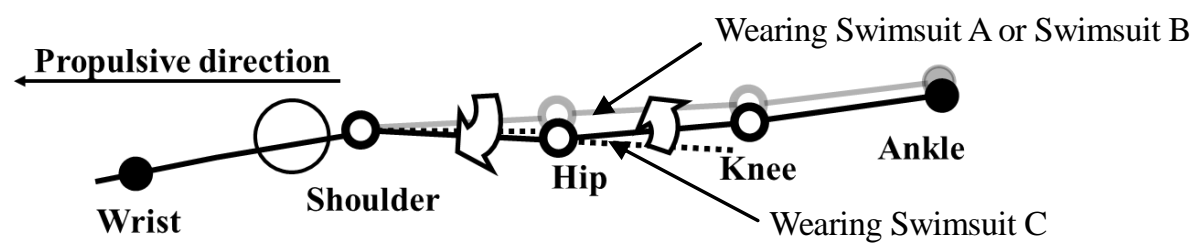

Fig.7 Example of difference of gliding position between the swimsuits

ここで，Swimsuit Cの構造に着目して，けのび姿勢に有意な違いが生まれた要因を考察する． Swimsuit C に用 いられている布帛素材は, Swimsuit A やSwimsuit B のニット素材と比べて張力が非常に強いという特徽がある. 加えて, どの水着を着用した際にも，慰部のふくらみなどにより背側（臀部側）の方が腹側と比較して体表に沿 った長さが長いため, 腹部側よりも臂部側の水着がより伸長する. 以上のことから, Swimsuit C を着用した際に は股関節が伸展する方向に大きな張力が働いたため, 股関節がより伸展するとともに推進方向に対して肩の位置 よりも腰の位置がより低い位置をとり，推進方向に対して慰部をより鉛直下向きに引っ込めた姿勢を取ったと考 えられる。

\section{$3 \cdot 2$ 水着が抗力係数に及ぼす影響}

図 8 に抗力係数の算出結果を示寸. 本研究におけるけのび時の抗力係数は平均 0.015 程度であり, 高木 ${ }^{(7)} ら の$ 研 究において示された值 $(0.03)$ と比較して半分程度であることが確認できる. ここで, 抗力係数の測定方法に着 目してみると，高木らの研究では水面付近を泳いだ際の抗力係数を測定しており，造波抵抗による影響を大きく 受ける. 一方, 本実験においては, 身体が完全に没水しているとともに, 水面からある程度離れた位置を推進し ているため，造波抵抗の影響が非常に小さく，抗力係数の值が高木らの值よりも小さくなったと考えられる.

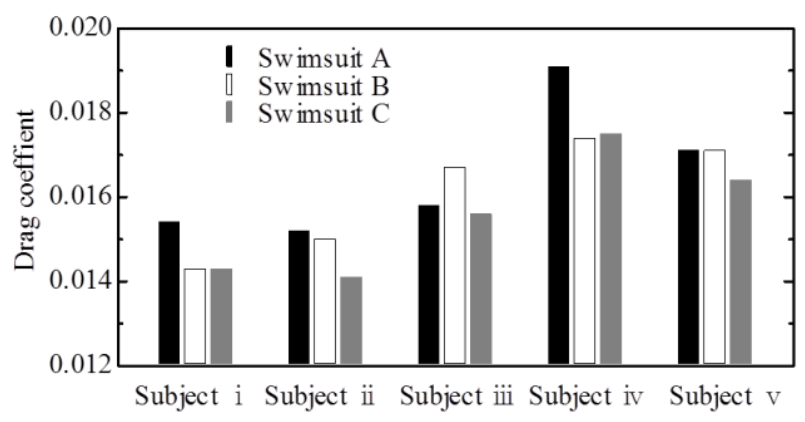

Fig.8 Results of drag coefficient 
次に，水着が抗力係数に及ぼす影響を調べるために，抗力係数についても，Welch の補正による一元配置分散 分析を用いて，水着間で一対一比較した．なお，被験者間のばらつきを抑えるために，片方の水着での抗力係数 によって正規化した值について，一元配置分散分析をおこなった．分散分析で取得した $p$ 值を表 4 に示す.

Table $4 \quad p$-level in ANOVA with normalized drag coefficient

\begin{tabular}{c|c}
\hline & All subjects \\
\hline Swimsuit A vs. Swimsuit B & 0.425 \\
\hline Swimsuit A vs. Swimsuit C & 0.012 \\
\hline Swimsuit B vs. Swimsuit C & 0.098 \\
\hline
\end{tabular}

表 4 より, Swimsuit A を着用した際と Swimsuit C を着用した際の抗力係数を比較すると, Swimsuit C を着用し た際の抗力係数が統計学的に有意に小さいこと $(p=0.012<0.05)$ が確認できる. しかし, Swimsuit B と Swimsuit C を比較した場合には, $p$ 值が 5\%以上であった。 ここで, Swimsuit B および Swimsuit C を着用した際の抗力係数に ついて, 図 8 と合わせて見てみると, Swimsuit C を着用した際の抗力係数は, Swimsuit B を着用した際の抗力係 数とすべて同程度もしくはそれ以下であることが確認できる. 以上のことから, 他の水着と比較して, Swimsuit C を着用した際の抗力係数は減少寸る傾向があると言える.このように抗力係数が減少する傾向が確認できた要因 については, 3.1 節で確認したけのび姿勢の変化による, 水泳時の圧力抗力の減少が考えられる.

\section{$3 \cdot 3$ 水着が筋活動に及ぼす影響}

まず，実験において取得した，腹直筋および脊柱起立筋の平均\%MVCを図 9 に示す．実験結果より，腹直筋の 筇活動は, Subject ii が Swimsuit A を着用した際の試技を除いて, 平均\%MVCが全て 4\%以下であり, 筇発揮が小 さいことが全被験者に共通して確認できる．このことから，けのび姿勢中は，どの水着を着用しても腹直筋の筋 活動がほとんどないと推測される.このため, 水着が腹直筋の筋活動に及ぼす影響は非常に小さいといえること から，以下では脊柱起立筋に着目し，水着が筋活動に及ぼす影響を考察する.

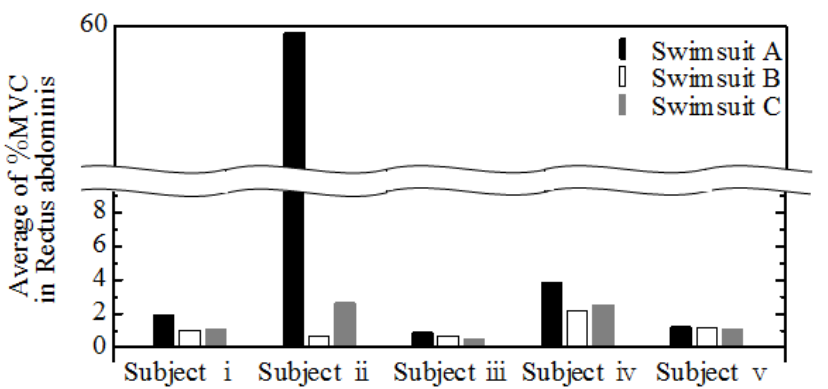

(a) Rectus Abdominis

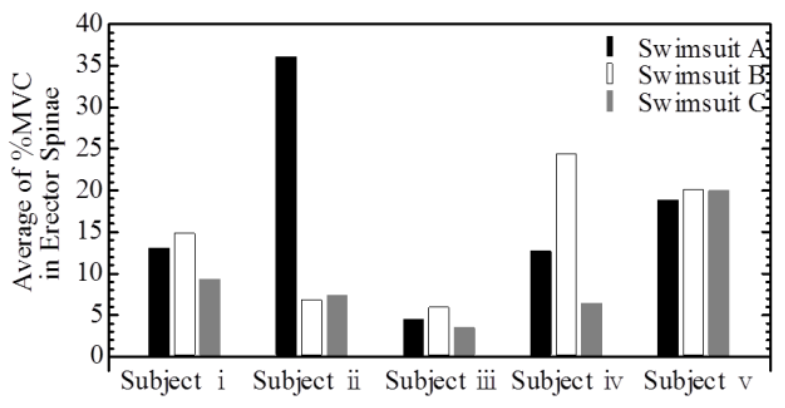

(b) Erector Spinae

Fig.9 Results of muscle activities 
そこで，関節角や抗力係数と同様に，Welch の補正による一元配置分散分析により，脊柱起立筋の平均\%MVC について水着間で一対一比較する. なお，片方の水着での平均\%MVCの值により正規化した值について，分散分 析をおこなうことによって, 被験者間のばらつきを抑えて筋活動を評価した，取得した $p$ 值を表 5 に示す.

Table 5 -level in ANOVA with normalized muscle activity of Erector Spinae

\begin{tabular}{l|c}
\hline & All subjects \\
\hline Swimsuit A vs. Swimsuit B & 0.666 \\
\hline Swimsuit A vs. Swimsuit C & 0.073 \\
\hline Swimsuit B vs. Swimsuit C & 0.120 \\
\hline
\end{tabular}

表 5 より，どの水着間の比較においても $p$ 值が 5\%以上であり，明確な有意差は確認できない，しかし，図 9(b) より, Swimsuit C と他の水着との比較において, Swimsuit C を着用した際の脊柱起立筋の筋活動は, 他の 2 種類 の水着を着用した際の值と同程度もしくはそれ以下であることが確認できることから，Swimsuit C を着用した際 の春柱起立筋の筋活動は減少する傾向があると考えられる.

\section{$3 \cdot 4$ 水着の体幹サポート効果}

3.1 および 3.3 節において，Swimsuit $\mathrm{C}$ 着用時に，けのび姿勢が股関節伸展気味に変化すること，および腹直筋 の筋活動は十分小さいままで脊柱起立筋の筋活動が減少寸る傾向があることが確認された．しかし，そもそもこ の両者は，体幹サポート効果としては同じものと考えられる．すなわち，3.1節で述べたように，Swimsuit Cでは 布帛素材の張力により，股関節を伸展させる効果が発生する．この効果は，ある被験者には，けのび姿勢は変わ らないままで, 股関節が伸展気味になる分だけ背中の筋肉の緊張をゆるめる（少しだけ背中を丸める）効果とし て現れる．また別の被験者には，背中の筋肉の緊張はそのままで，けのび姿勢が股関節伸展気味に変化する効果 として現れる. 寸なわち, 効果としては同じでも, その現れ方（けのび姿勢への影響と筋活動への影響の割合） は被験者ごとに異なると考えられる，そこで本節では，けのび姿勢と脊柱起立筋の筋活動の両者を考慮した，体 幹サポート効果を表す新たな評価指標を定義し，本指標の結果について考察する.

\section{$3 \cdot 4 \cdot 1 \quad$ 体幹サポート効果の評価指標}

体幹サポート効果としては，上記で述べたように，けのび姿勢（股関節角）と脊柱起立筋の筋活動の二つの要 素がある．しかし例えば，股関節角の変化を，相当する脊柱起立筋の筋活動に置き換えることができれば，筋活 動のみとして統一的に体幹サポート効果を表現することが可能となる．そこでまず，股関節角と春柱起立筋の筋 活動の関係を取得することを考えた．そのため， 3.1 および 3.3 節において，Swimsuit A および Swimsuit B がけの び姿勢と筋活動に及ぼす影響に有意差がないことが確認できたことから, Swimsuit A および Swimsuit B における 実験結果を，水着による影響がないものと仮定して用いることとした。

まず，Swimsuit A と Swimsuit B を着用した際の股関節角と脊柱起立筋の平均\%MVC の平均值を被験者ごとに それぞれ算出した。 続いて, 試技ごとに, 股関節角については平均值との差 (股関節角差) を, 春柱起立筋の平 均\%MVCについては平均値により正規化した值を算出した。 これらの手順によって得られた值を, 横軸に股関節 角差，縦軸に正規化した春柱起立筋の平均\%MVC としたグラフにプロットした. 得られた結果を図 10 に示す. 


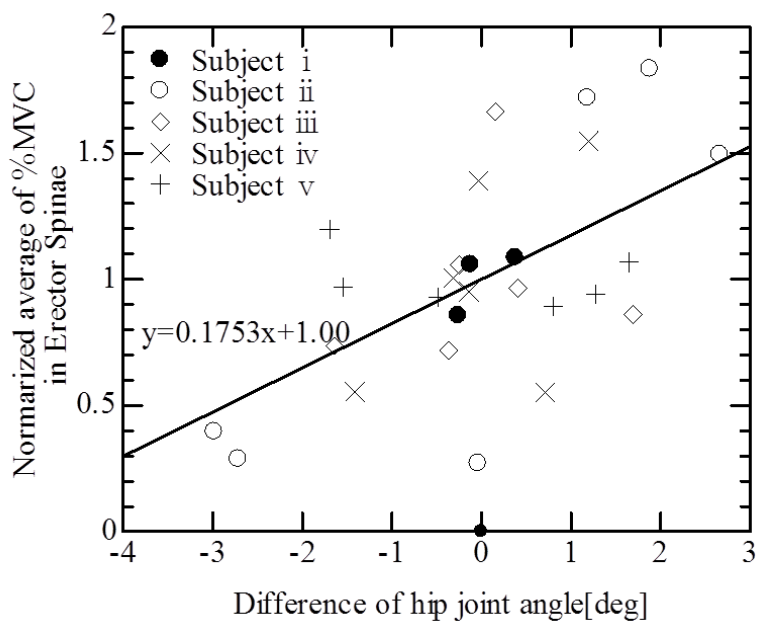

Fig.10 Difference of hip joint angle and normalized average of \%MVC in Erector Spinae

次に, 図 10 において, 股関節角差と正規化した春柱起立筋の平均\%MVCについて, その相関を調べたところ, 相関係数が 0.583 であったことから, 2 つの值はばらつきはやや大きいものの, 概补 1 次関数的な関係にあるとい える. そこで，最小二乗法を用いて線形近似をおこなったところ，図 10 に示すように，傾き 0.1753 , 切片 1.00 の 1 次式を得ることができた.

ここで，図 10 に示した 1 次式の傾きは，股関節角差に対して脊柱起立筋の平均\%MVCがどの程度変化するの かを示していることから，この傾きの值を用いれば，股関節角の変化を脊柱起立筋の筋活動の変化に置き換える ことができる.よってこの值を用いて, 股関節角の変化分を補正した脊柱起立筋の筋活動の評価式, すなわち体 幹サポート効果の評価指標 $S$ を次の式(5)のように定義した。

$$
S=A c t-0.1753 \times d \theta
$$

式(5)において, Act は Swimsuit A もしく Swimsuit B 着用時の平均\%MVC の值によって正規化した脊柱起立筋の平 均\%MVC， $d \theta$ は Swimsuit A もしくは Swimsuit B 着用時の股関節角との股関節角差である.

\section{$3 \cdot 4 \cdot 2$ 新たな評価指標を用いた考察}

次に, 3.4.1 項で示した評価指標 $S$ につい, その值を被験者ごとに算出し, 水着がけのび姿勢および笳活動に 及ぼす影響を考察する。

まず, $S$ の值を表6に示す.表6において, $S_{a a}$ およ゙ $S_{c a}$ は Swimsuit Aの值を基準に算出した Swimsuit A と Swimsuit $\mathrm{C}$ 着用時の $S$ の值, $S_{b b}$ および $S_{c b}$ は Swimsuit B の值を基準に算出した Swimsuit B と Swimsuit C 着用時の $S$ の值で

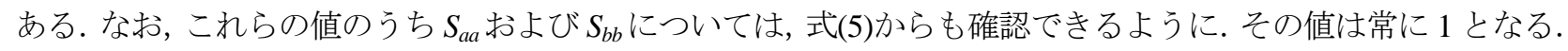


Table 6 Values of index $S$

\begin{tabular}{|c|c|c|c|c|}
\hline & \multicolumn{2}{|c|}{ Swimsuit A vs. Swimsuit C } & \multicolumn{2}{|c|}{ Swimsuit B vs. Swimsuit C } \\
\hline & $S_{a a}$ & $S_{c a}$ & $S_{b b}$ & $S_{c b}$ \\
\hline Subject i & 1.000 & 0.472 & 1.000 & 0.486 \\
\hline Subject ii & 1.000 & 0.613 & 1.000 & 0.556 \\
\hline Subject iii & 1.000 & 0.579 & 1.000 & 0.187 \\
\hline Subject iv & 1.000 & 0.077 & 1.000 & -0.014 \\
\hline Subject v & 1.000 & 0.791 & 1.000 & 0.605 \\
\hline
\end{tabular}

算出した值について，関節角や筋活動を考察した際と同様に，Welch の補正による一元配置分散分析により， 水着間で一対一比較した. 分散分析で取得した $p$ 值を表 7 に示す.

Table $7 p$-level in ANOVA with S-value

\begin{tabular}{c|c}
\hline & All subjects \\
\hline$S_{a a}$ vs. $S_{c a}$ & 0.014 \\
\hline$S_{b b}$ vs. $S_{c b}$ & 0.006 \\
\hline
\end{tabular}

表 7 から確認できるように，算出した $p$ 值がともに $5 \%$ 未満であることから， Swimsuit C を着用した際の $S$ の 值は, Swimsuit A および Swimsuit B を着用した際と比べて, 統計学的に有意に減少しているといえる. すなわち, Swimsuit C の体幹サポート効果が確認できた。 また，表 7 の $p$ 值は, 3.1 節の表 2 , 表 3 , および 3.3 節の表 5 に おける $p$ 值より明らかに小さくなっており，体幹サポート効果の新たな評価指標を導入することによって，傾向 のより明確な把握が可能になったと考えられる.

\section{4. 結}

本研究では, 3 種類の競泳用男性水着（Swimsuit A : ニット素材を用いたショートスパッツ型水着, Swimsuit B : ニット素材を用いたハーフスパッツ水着, Swimsuit C : 体幹サポート効果が期待される, 布帛素材を用いたハー フスパッツ水着）を用いて，被験者 5 名に対して，けのび姿勢と脊柱起立筋および腹直筋の筋電図を同時測定し た．また，水中撮影映像から，抗力係数，肩関節，股関節，膝関節の伸展・屈曲方向の関節角，および推進方向 に対する体幹の水面方向に対する絶対角を算出した.

次に, Welch の補正による一元配置分散分析を用いて，実験結果について水着間で一対一比較をおこない，水 着がけのび姿勢および筋活動に与える影響を検討した，その結果，Swimsuit C を着用した際には Swimsuit A およ び Swimsuit B を着用した際と比較して, 股関節がより伸展していること $(\mathrm{p}<0.05)$, 推進方向に対して肩の位置よ りも腰の位置がより低くなること $(\mathrm{p}<0.05)$ を確認した. また, Swimsuit C を着用した際には他の水着を着用した際 と比較して, 抗力係数が減少する傾向があること, 腹直筋の筋活動はほとんどないにも関わらず脊柱起立筋の筋 活動が減少する傾向があることを確認した.

加えて, 股関節角の変化分を補正した脊柱起立筋の筋活動として体幹サポート効果の新たな評価指標を定義し, その評価指標の值より，Swimsuit Cの体幹サポート効果を確認した．なおこの原因は，Swimsuit Cで用いられて いる布帛素材による強い張力による股関節伸展効果のためと考えられる. 
謝辞

本研究における実験の遂行にあたっては, 中央大学准教授 高橋雄介氏に多大なるご協力をいただいた. 記して 謝意を表する.

\section{文献}

(1) Toussaint,H.M., Truijens,M., Elzinga,M., De Ven,A.V., De Best,H., Snabel,B., and De Groot,G., "Effect of a Fast-skin 'Body'suit on Drag during Front Crawl Swimming”, Sports Biomechanics, Vol.1, No.1(2002), pp.1-10.

（2）清水幸丸, 鈴木利明, 鈴木邦仁, 清川寛, “競泳用水着の抵抗測定に関寸る研究”, 日本機械学会論文集 B 編, Vol.63, No.616(1997), pp.107-113.

（3）猪飼道夫，石井喜八，宮下充正，“水泳中の筋電図”，Olympia，Vol.2，(1961)，pp.258-263.

(4) Pink,M., Perry,J., Browne A, Scovazzo,M.L., and Kerrigan,J., "The normal shoulder during freestyle swimming”, The American Journal of Sports Medicine, Vol.19, No.6(1991), pp.569-576.

(5) Dankaerts,W., O'Sullivanet,P.B., Burenett,A.F., Straker,L.M., and Danneels,L.A., "Reliability of EMG measurements for trunk muscles during maximal and sub-maximal voluntary isometric contractions in healthy controls and CLBP patients" , Journal of Electromyography and Kinesiology, Vol.14, (2004), pp.333-342.

（6）木塚朝博，増田正，木竜徹，佐渡山亜兵，表面筋電図，(2006)，p.13-46，東京電機大学出版局.

（7）高木英樹, 清水幸丸, 小段範久, “水泳における自己推進時抵抗に関寸る流体力学的研究”, 日本機械学会論文集 B 編, Vol.64, No.618(1998), pp.79-85.

(8) 松浦義行, 体力測定法, (1989), p.159-162, 朝倉書店.

(9) 対馬栄輝, “リハビリテーション分野の研究で用いられる統計手法”, バイオメカニズム学会誌, Vol.35, No.1(2011), pp.67-75. 